\title{
Pilar: um núcleo habitacional para a indústria mineradora na caatinga baiana
}

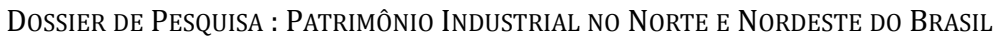

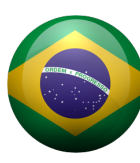

\section{Ana Gabriela Wanderley Soriano}

Arquiteta e Urbanista. Doutoranda do Programa de Pós-Graduação em Arquitetura e Urbanismo da Faculdade de Arquitetura da Universidade Federal da Bahia. Professora da Faculdade de Arquitetura da Universidade Federal da Bahia. Salvador [Bahia] Brasil.<gabrielaws@hotmail.com>

\section{Resumo}

0 impulso econômico dos anos de 1970 e o despertar do planejamento urbano patrocinaram a criação de núcleos habitacionais no cenário da mineração, provocando o deslocamento de capital e mão-de-obra pelo Brasil. Tais assentamentos nasceram sob a tutela das empresas mineradoras e, em alguns casos, amadureceram e tornaram-se independentes. Se por um lado a exploração dos minérios foi o propulsor do surgimento de núcleos urbanos de apoio à mineração pelo interior do país, por outro lado o seu fracasso ou fim selou e traçou o destino de diversas localidades. Implantado no Vale do Curaçá, na caatinga baiana, Pilar, hoje distrito de Jaguarari, foi projetado para abrigar os trabalhadores envolvidos na extração do cobre pela Mineração Caraíba S/A. Para o desenvolvimento do projeto do Núcleo Residencial do Pilar, no final da década de 1970, foi contratada a equipe do arquiteto Joaquim Guedes. 0 objetivo, portanto, do presente trabalho é discorrer a respeito da criação e da história de Pilar, analisando a sua conformação arquitetônica e urbanística, como um núcleo urbano surgido como apoio às atividades de exploração de cobre e a importância de preservação deste patrimônio industrial.

\section{Palavras-chave}

Pilar. Patrimônio industrial. Urbanismo modernista.

\section{Pilar: a housing nucleus for the mining industry in the Bahian caatinga}

\begin{abstract}
The economic impulse of the 1970s and the rise of urban planning fomented the creation of housing nuclei in a predominant mining scenario, causing the dispersion of capital and labor across Brazil. Such settlements arose under the tutelage of mining companies, and some managed to become independent. On one hand the exploitation of the ores was the propeller of the emergence of urban centers, which supported the mining activities at the countryside. On the other hand its failure or end sealed and traced the destiny of several localities. Pilar, currently a district of Jaguarari, is situated in Vale do Curaçá, in the Bahian Caatinga. Pilar was designed to house the workers involved in the extraction of copper by Mineração Caraíba S/A, which hired the team of the architect Joaquim Guedes to develop the project Núcleo Residencial do Pilar, in the late 1970s. The objective of this work is to discuss the creation and history of Pilar, analyzing its architectural and urbanistic conformation as an urban nucleus emerged as a support for copper exploration activities, and appreciating the importance of preserving this industrial heritage.
\end{abstract}

\section{Keywords}

Pilar. Industrial heritage. Modernist urbanism. 


\section{Introdução}

Em meados dos anos 1960 e princípios da década de 1970, o Brasil vivenciou o período que ficou conhecido como "milagre econômico", onde um forte impulso econômico visou promover, além do crescimento do país, a integração nacional com a implementação de diversos programas e projetos nos setores de transporte, energia, indústria e habitação. Importantes obras de infraestrutura, especialmente as ligadas à exploração dos recursos naturais disponíveis, foram executadas por todo o país no bojo do tal "avanço econômico" que se vivenciava naquele momento. Foram hidrelétricas, estradas, pontes, instalação de pólos industriais, entre outras grandes obras, que contaram com fortes incentivos fiscais e investimentos, que acarretou em um notável crescimento da produção de bens duráveis, impulsionando efetivamente a economia do país. Para tanto, e neste cenário, o governo não poupou esforços nem investimentos na construção de significativas obras que proporcionassem a viabilização da exploração dos recursos naturais descobertos, especialmente pelo interior do país.

É neste contexto, que, nos anos 1970, foram patrocinados e criados alguns importantes núcleos habitacionais sob a égide da mineração, o que provocou o deslocamento de capital e mão-de-obra pelo país. Estes assentamentos nasceram sob a tutela das empresas mineradoras e, em alguns casos, amadureceram e tornaram-se independentes, ganhando sua autonomia política e econômica através de investimentos em outros setores, impulsionados pela diminuição ou esgotamento das fontes minerais. Se por um lado a exploração dos minérios foi o propulsor do surgimento destes núcleos urbanos de apoio à mineração pelo interior do país, por outro lado o seu fracasso ou fim selaria e traçaria o destino de diversas localidades. Os assentamentos implantados tornaram-se verdadeiras incógnitas quanto ao seu futuro, alguns já apontam alguns resultados: seja através de uma nova direção administrativa, seja, em certos casos, na transformação desses núcleos em verdadeiras cidades mortas.

Nas diversas experiências pelo país - Vila Serra do Navio, no Amapá, Vila Nova de Carajás e Vila Nova de Barcarena, ambas no Pará, entre outras - podem ser ressaltadas algumas características de concepção projetual em comum: inicialmente por se tratarem de núcleos habitacionais criados para dar apoio urbano a um estabelecimento industrial, muitas vezes bastante isolados; a concepção de um espaço cívico central onde contasse com serviços administrativos, culturais, comerciais e de serviços; a eliminação dos muros das residências; a presença de habitações individuais e/ou coletivas para os funcionários solteiros; e, a ausência de equipamentos de controle da segurança local como delegacia, presídios.

Quando se procura estudar e compreender os destinos desses núcleos urbanos é necessária uma comparação entre o planejamento inicial - no intuito de entender as principais diretrizes no âmbito da morfologia, planos, programas - e a realidade atual do lugar, verificando até que ponto a ideia contida no papel, inicialmente, se materializou ou não no espaço concreto da cidade real e quais são as suas verdadeiras disposições.

\section{A exploração do cobre no sertão baiano}

Nos anos 1960, o industrial Francisco Pignatari, proprietário da Companhia Brasileira do Cobre (CBC), entusiasmou-se por desbravar o sertão baiano ao abraçar o Projeto Caraíba - nome da antiga fazenda que ocupava o sítio. Ele via um grande futuro para a mina de cobre da qual se teve conhecimento pela primeira vez em 1874. As primeiras escavações na mina foram feitas ainda em 1900, pelo engenheiro Francisco de Paula Oliveira, quando foi perfurado um poço de $14 \mathrm{~m}$ de profundidade. Somente em 1934 a mina foi registrada no Departamento Nacional de Mineração em nome da Mineração Northfield, do Canadá. Seis anos depois, em plena Segunda Guerra Mundial, o controle foi passado à Caraíba Mineração e Metalurgia S.A. Em 1974, o empreendimento passou a ser controlado pelo Banco Nacional de Desenvolvimento Econômico e Social (BNDES). Em 1976, o Ministério da Indústria e Comércio aprovou a instalação das unidades de concentração e metalurgia do cobre do Projeto Caraíba. A implantação da exploração da jazida possibilitou que a Bahia se tornasse o principal estado brasileiro produtor de cobre, responsável por três quartos da produção nacional ${ }^{1}$.

1 Filho, R. da S. A riqueza do sertão da Bahia. Recuperado de: http://www.minerios.com.br/277/minerios_cobre2.htm. 
O início da mineração de cobre na região de Caraíba se deu de fato em 1978, há exatas 4 décadas, com a exploração da chamada "mina a céu aberto", com a previsão de atividade por 20 anos, onde era extraído o cobre em camadas que se exauriam a cada 20 metros (Figura 1). Em 1988, a Mineração Caraíba foi desmembrada da Caraíba Metais Metalúrgica. Em outubro de 1994, no governo Itamar Franco, a empresa foi desestatizada, dentro da política de privatização do então governo. Em setembro de 1998, a exploração da mina a céu aberto se esgotou ocasionando a sua desativação, o que significou a perda de $50 \%$ da capacidade de geração de emprego e renda, fazendo com que o núcleo sentisse um grande impacto sócio-econômico. A partir de então, começou a investida na mina subterrânea, localizada abaixo da antiga, em uma operação realizada a uma profundidade de $800 \mathrm{~m}$ da superfície. Os empregos nesta nova fase foram assegurados através do Projeto Mina do Futuro, onde a Mineradora investiu pesado para a continuidade da exploração

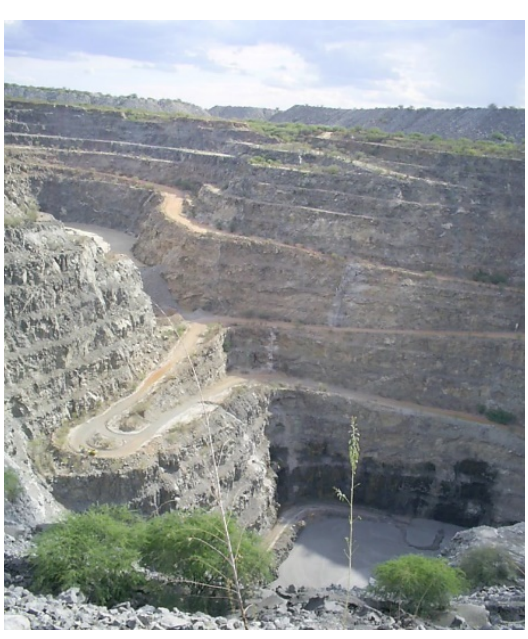

Figura 1. Mina a céu aberto. Fonte: Bortolini, s./d. de cobre.

\section{0 distrito do Pilar}

O distrito do Pilar2 ${ }^{2}$ do município de Jaguarari, a antiga cidade de Caraíba, está implantado no Vale do Curaçá, na caatinga baiana, a noroeste de Salvador. No final da década de 1970 e princípio de 1980, o núcleo habitacional foi projetado e construído tendo como finalidade abrigar os empregados da mineração de cobre da Mineração Caraíba S/A, os prestadores de serviços indiretos bem como seus familiares. Em sua concepção original, a nova cidade atenderia um número de aproximadamente 8 mil habitantes, podendo chegar, em uma perspectiva de crescimento, a uma população de 15 mil. Para tal empreitada foi contratada a equipe coordenada pelo arquiteto Joaquim Guedes, no período de 1976 a 1982, que projetaria o Núcleo Residencial do Pilar e coordenaria a execução do projeto. Neste contexto, a implantação do núcleo habitacional urbano apoiaria as atividades industriais e a própria sede da empresa, não estando livre das características inerentes a este tipo de assentamento ao encontrar-se isolado, em uma paisagem peculiar e fortemente marcada pela presença de uma grande companhia, esta que definiria e influenciaria na construção e administração do núcleo.

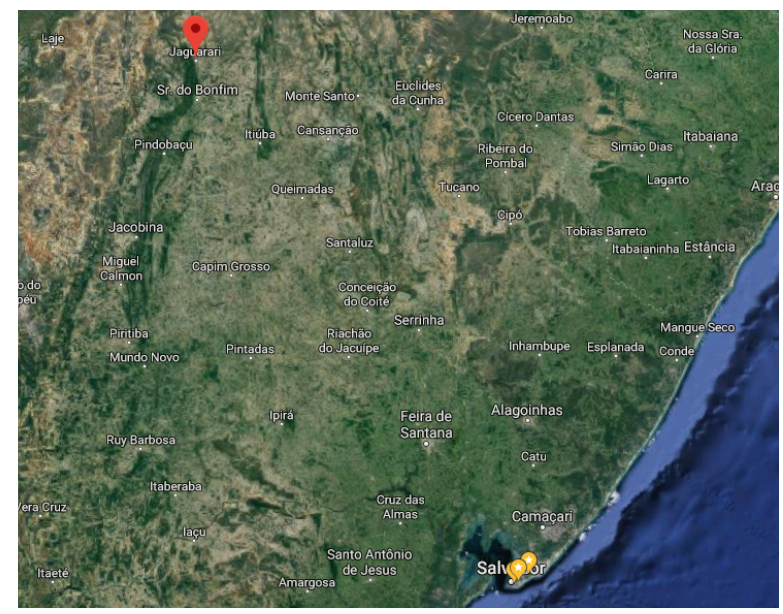

Figura 2. Localização de Jaguarari [BA]: aproximada/e. $410 \mathrm{~km}$ de Salvador.

Fonte: GoogleEarth, 2018.

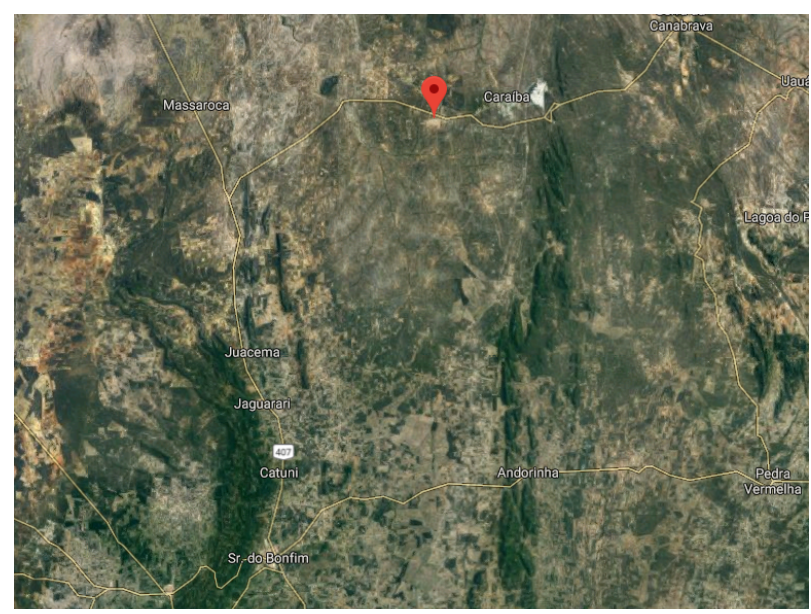

Figura 3. Localização do Distrito do Pilar: aproximada/e. $70 \mathrm{~km}$ da sede do município de Jaguarari [BA]. Fonte: GoogleEarth, 2018.

Joaquim Guedes também foi responsável pelos projetos de outros núcleos habitacionais que se destinariam a dar suporte a empresas de exploração de minerais no interior do Pará: Marabá, em

2 Pilar passou a categoria de distrito de Jaguarari através do Decreto Municipal no 466/95, de 15 de dezembro de 1995. 
1973, que não chegou a ser executado, como núcleo de apoio à extração de minério de ferro; e, em 1978, contemporâneo à cidade de Caraíba, Guedes foi também contratado para a elaboração do plano urbanístico de Vila Nova de Barcarena, no Pará. Este último projeto nasce como apoio à implantação da empresa Albrás/Alunorte e, assim como no projeto do Pilar, o arquiteto tentou fugir da concepção de espaços segregadores:

Guedes idealizava criar uma "cidade aberta" a todos que a procurasse, onde não houvessem diferenças nem segregação, onde todos pudessem ter acesso aos espaços públicos da cidade, onde as interações sociais pudessem ser desenvolvidas sem problemas. (Farias, 2003).

Em uma tentativa de evitar a segregação espacial, destino notadamente manifestado em cidades planejadas, Guedes buscou, de uma forma cuidadosa, a exemplo do Pilar, não evidenciar tais diferenças mesclando as habitações, procurando não distinguir espacialmente os distintos estratos sociais, evidenciados na arquitetura pelos níveis hierárquicos dentro da empresa. Além desta escolha projetual, o arquiteto também assinalou espacialmente, dentro de uma malha rigidamente ortogonal, o que viria a ser o centro do núcleo, marcado por um grande espaço público circundado por edifícios de maior gabarito que abrigaria habitações e comércio.

Ao se observar os traçados urbanísticos e, principalmente, as características arquitetônicas do projeto de Guedes, pode-se encontrar uma clara influência, mesmo que inconscientemente e não declarada, das cidades do carvão da Sardenha. 0 complexo das "cidades do carvão" foi construído entre os anos de 1937 e 1940, visando "resolver o problema energético da nação depois da redução das importações inglesas" (Sanna, 2003:103). Este complexo é formado pelas cidades de Arsia (1937) e Pozzo Littorio (1940), ambas hoje em território croata, e por Carbonia (1938) e Cortoghiana (1940), na região sul-ocidental da ilha mediterrânea da Sardenha.

Especial influência percebe-se nesta última: Cortoghiana. A vila de Cortoghiana foi projetada em 1940 pelo então jovem arquiteto romano Saverio Muratori, que:

[...] além de assumir os princípios da cidade-jardim do século XIX, os moderniza fazendo referências aos pontos mais avançados do urbanismo europeu e italiano, como as siedlungen alemães e as teorizações sobre a cidade horizontal e os bairros racionais modernos (Sanna, 2003, p.107).

Assim como Muratori, Guedes evidenciou os edifícios centrais a partir de um gabarito mais elevado em relação as demais construções ${ }^{3}$, marcando assim um centro cívico da cidade, implantado, em ambas cidades, circundando a praça central. São edifícios em grandes blocos contínuos e extensos traduzido por uma perspectiva imponente e sólida, sob pilotis, com aberturas em ritmo e dimensões constantes em toda sua extensão. Em ambos se evidencia uma quebra na superfície, sendo no caso de Cortoghiana feita a partir de um pequeno e discreto recuo na fachada, enquanto que no caso de Pilar, Guedes optou por uma quebra mais impactante com o aumento dos pilotis e a inserção de um vazio buscando interromper a leitura do conjunto maciço (Figuras 4 e 5). Em ambos projetos, tratam-se de construções de uso misto, onde nos pavimentos superiores abrigam os alojamentos e apartamentos e o pavimento térreo destinado a estabelecimentos de comércio e serviços.

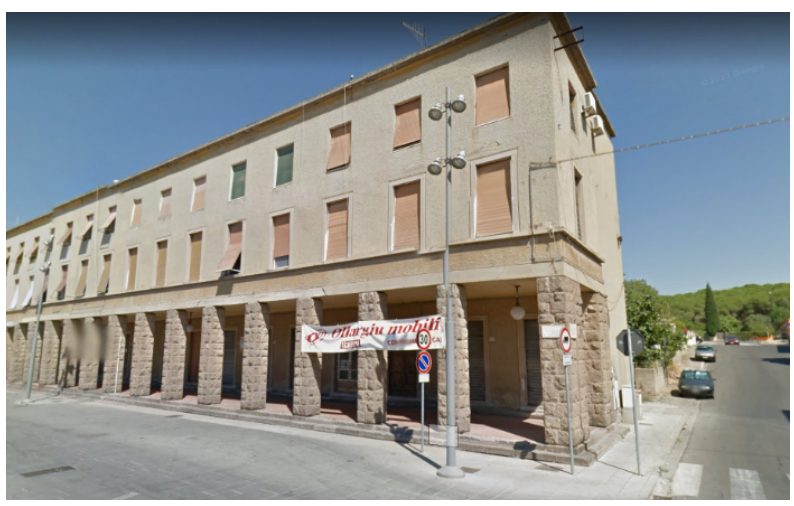

Figura 4.

Cortoghiana, Sardenha. Fonte: Google, imagem captada em agosto de 2012.

\footnotetext{
${ }^{3}$ No caso de Cortoghiana, observa-se que há construções com térreo e mais um pavimento, enquanto que no caso do Pilar, as demais construções são exclusivamente térreas.
} 
4. 0 projeto

De apoio a mineração de cobre, reserva limitada a exploração por 20 anos. Concurso. Recebemos apenas o mapa da planície chapada e infraestrutura industrial sem curva de nível com uma relação de espaços classificados por renda e função. Os estudos para caracterização dos fundamentos sociais e econômicos duraram 1 ano durante o qual a cidade foi sendo imaginada e conceituada, localização, critérios construtivos, infraestrutura, clima, habitação, níveis de oferta de serviço e forma. Sugerimos malha compacta, para mínimo deslocamento na região semiárida, com centro denso para solteiros não confinados $e$ dispersos e 20\% das famílias. 0 sistema urbano constituído por agregação modular livremonitorada, sobre uma trama-conceito básica, com reserva de área para população não empregada, de livre acesso, dimensionada em 10\% da população total (Guedes, 2006).

As obras do Núcleo Residencial do Pilar foram iniciadas em 1976, e contava com um extenso programa a ser atendido. Com a função de dar suporte e apoio aos trabalhadores da mineradora, o núcleo deveria, portanto, ser pensado, em todas as suas características iniciais, para uma comunidade que nele habitaria e como essa demandaria e se apropriaria do espaço planejado, procurando atender às necessidades naturais de uma população, dando especial atenção aos fatores climáticos e das condições econômicas e sociais envolvidas, bem como ao aspecto paisagístico peculiar e marcante. Neste sentido, o programa do projeto do núcleo deveria atender minimamente à fixação dos trabalhadores de forma a proporcionar um melhor conforto em meio à caatinga baiana.

A área do núcleo, originalmente, era de aproximadamente 2 milhões de metros quadrados. A implantação do projeto se deu em 4 etapas, sendo realizada por diferentes construtoras no decorrer do tempo, tendo a última etapa sido executada em 1985. Durante sua história, o núcleo sofreu algumas alterações sem que este fato desfigurasse, inicialmente, de forma mais radical, o traçado e a arquitetura original do plano. Porém, o que se pode visualizar atualmente são algumas intervenções ${ }^{4}$ que buscam atender demandas contemporâneas e, principalmente, uma readaptação física local a uma nova configuração, na tentativa de promover sua sustentação, tendo em vista que as perspectivas em relação à mineradora não são otimistas.

O plano, em seu programa original, contava com: habitações (divididas em casas, apartamentos, alojamentos e um apart hotel), edifícios comerciais, 2 escolas de pré-escolar, 2 escolas de 1 o e $2^{\circ}$ o grau, 2 clubes sociais, 1 hospital, 3 agências bancárias, estação de tratamento de esgoto, estação de tratamento de água e vias públicas asfaltadas.

\subsection{Traçado}

O sítio onde está implantado o núcleo é bastante plano e circundado por uma vegetação característica da caatinga (Figura 6). A ligação do núcleo, hoje distrito de Jaguarari, com a sede do município se dá através da BA-314, estando Pilar a cerca de $70 \mathrm{~km}$ do centro de Jaguarari e não existindo algum povoado nas proximidades, ficando, assim, isolada.

0 traçado da cidade se desenvolve ortogonalmente com quadras dimensionadas uniformemente - aproximadamente $64,00 \times 284,00 \mathrm{~m}$ - ao longo da extensão exterior ao núcleo central, onde está localizado o

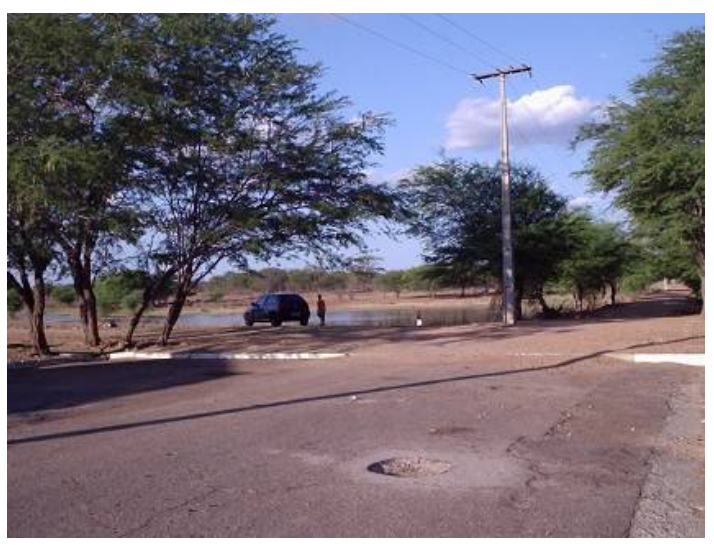

Figura 6. Limites do Núcleo, vegetação típica. Fonte: acervo próprio. setor comercial do Pilar. Neste, desenvolve-se seis grandes quadras, com dimensões figurativas aproximadas a um quadrado, onde localizam, além do comércio, escolas, residências em apartamentos, praças, mercado. Duas dessas quadras centrais contíguas foram destinadas a praças públicas, marcando, assim, um grande centro de atividades do núcleo.

\footnotetext{
${ }^{4}$ As intervenções observadas se deram em algumas residências onde foram instalados comércios e serviços, de forma improvisada, como meio de prover o sustento das famílias e atendendo a demandas que surgiam com o aumento e diversificação da população.
} 
A cidade apresenta, dentro do seu traçado rigorosamente ortogonal, praças que se localizam em pontos estratégicos do plano, possibilitando espaços públicos livres em localizações devidamente estudadas, de forma a atender uma vizinhança mais imediata com um equipamento que promova a interação e convivência social. Portanto, além do grande espaço público central destinado a duas grandes praças rodeadas marcadamente pelos edifícios centrais de gabarito mais elevado, o distrito do Pilar conta também com outras 6 (seis) praças, distribuídas "uniformemente" pelo plano, conjugadas a escolas e/ou comércios locais, conforme pode ser observado nos itens 14 e 15 do plano (Figura 7).

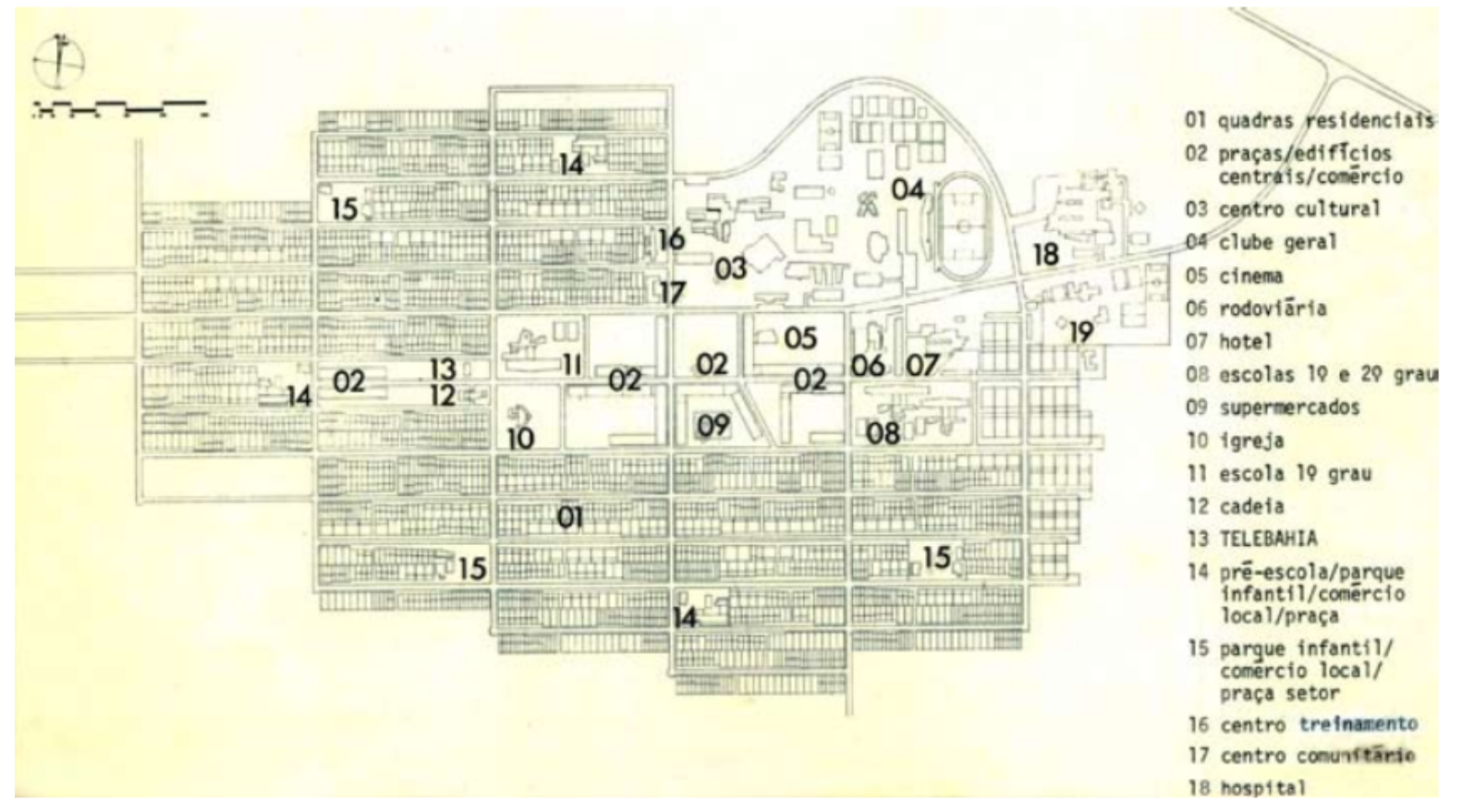

Figura 7. Plano de implantação do Pilar. Fonte: Guedes, 2006.

\subsection{Os Edifícios Centrais}

Os edifícios centrais são caracterizados por possuírem o pavimento térreo - com uma área sob pilotis - destinado a estabelecimentos comerciais e de serviços, e mais dois pavimentos superiores destinados a residências (alojamentos e apartamentos). 0 centro dessas quadras é caracterizado por possuírem um grande espaço aberto, como um pátio. Estas edificações diferem do gabarito geral do núcleo, caracterizado por edificações térreas tendo pouquíssimos exemplares de mais de um pavimento - estes exemplares configuram-se na descaracterização do plano original onde os moradores adaptaram as residências a outros usos, como, por exemplo, pousadas.

Esta morfologia arquitetônica muito se aproxima das edificações de Cartoghiana, na Sardenha, mencionadas anteriormente, onde os edifícios centrais também possuem um recuo, no térreo, sob pilotis proporcionando um passeio pelo setor comercial abrigado. No caso de Pilar, tal solução veio como forma de garantir um melhor conforto térmico tanto para os comerciantes quanto para a população transeunte. Ao se passear pelas lojas abrigadas no térreo dessas edificações pode-se abrigar do forte sol da caatinga nordestina. Observa-se no caso do Pilar que os edifícios localizados na face sudeste da praça possuem os pilotis mais elevado, abrigando uma espécie de sobreloja no pavimento térreo, enquanto que os edifícios da face nordeste da praça apresentam um piloti mais baixo ocupado apenas pelo comércio ali instalado.

Outro ponto interessante de se mencionar é a opção das cores do arquiteto. As residências unifamiliares e os equipamentos foram planejados para serem na cor branca e com elementos em madeira, conforme serão analisados mais à frente, já os edifícios centrais se destacam não apenas pela sua altura, sua massa, mas também pela aplicação de cores em faixas, em tons pasteis, que se diferenciam das demais arquiteturas do núcleo. A escolha das cores foi, provavelmente, influenciada pela paisagem local, de semiárido, onde o arquiteto buscou não só distinguir os edifícios das demais edificações, mas também destacá-la dentro da paisagem sem agredi-la (Figura 10). 


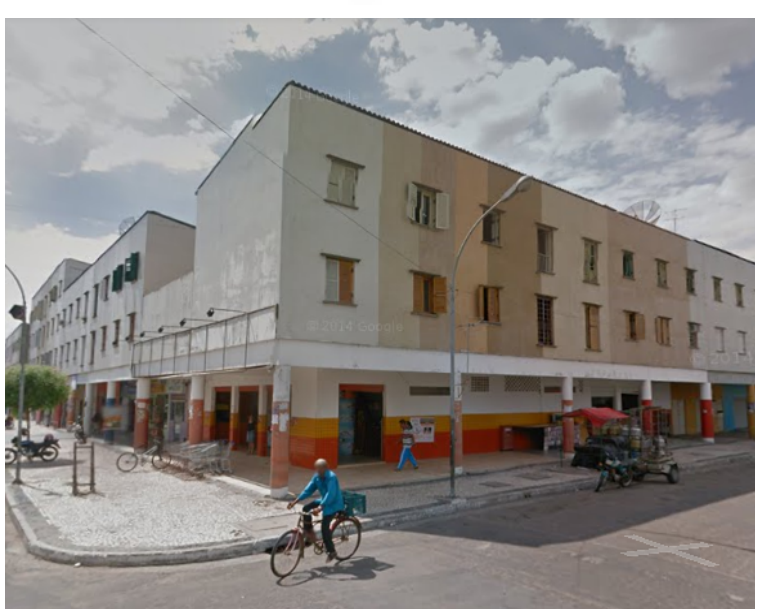

Figura 8. Edifícios centrais, face nordeste da praça. Fonte: Google, imagem captada em novembro de 2012.

\subsection{As Praças}

As duas principais praças públicas do núcleo (Figura 10) tem em seu entorno as edificações centrais que abrigam boa parte do comércio local. Essas praças têm importante papel no convívio social do núcleo, especialmente no período noturno, quando o clima está mais ameno e as atividades dos moradores proporcionam o convívio no espaço público. É também neste espaço central que se concentram os principais eventos sociais, políticos e culturais acontecem neste centro, fazendo com que os moradores criem o hábito de se deslocarem para este sítio para seu lazer.

A praça Ariomar Rocha, a praça principal (Figura 11), de maior dimensão, passou por uma recente reforma, modernizando a linguagem arquitetônica e inserindo novos equipamentos. 0 tratamento do piso foi todo executado em pedra portuguesa, sendo introduzidos bancos, objetos "decorativos", nova iluminação valorizando o novo projeto, parque infantil, jardins, um pequeno anfiteatro, quadra esportiva. 0 projeto possui uma linguagem que difere da arquitetura de seu entorno, trazendo novos elementos formais contemporâneos, apesar de tentar buscar uma identificação apenas nas cores com a arquitetura do seu entorno.

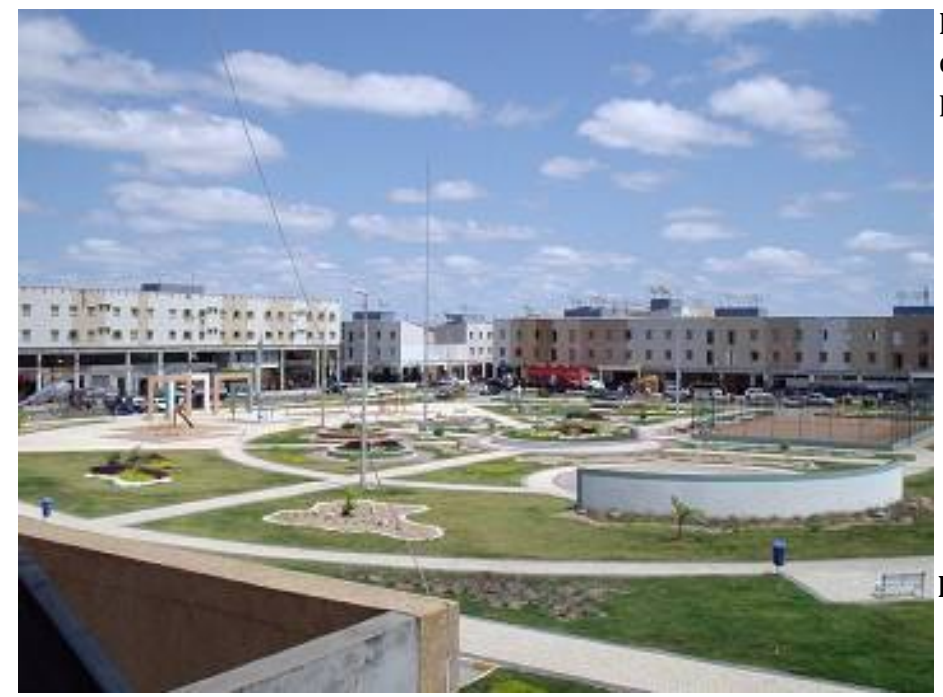

Figura 11. Praça Ariomar Rocha vista a partir de um dos edifícios do entorno. Fonte: acervo próprio.

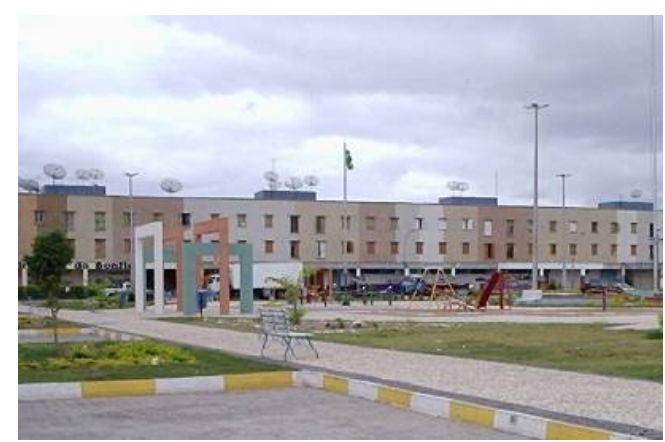

Figura 12. Equipamentos: banco, parque, parque infantil, elementos decorativos, entre outros. Fonte: acervo próprio. 
A intervenção na praça principal de Pilar tenta atender a demandas da população, tendo em vista que os espaços destinados a implantação de praças públicas, planejadas por Joaquim Guedes, nunca foram completamente executadas, conformando-se como áreas abertas desprovidas de equipamentos que as qualificassem. As praças "periféricas" acabaram por se configurar como terrenos descampados, muitas vezes, criando apenas um espaço amplo em frente a alguns equipamentos do núcleo, mas sem receber elementos que possibilitassem um uso mais intenso e direcionado do espaço público (Figura 13).

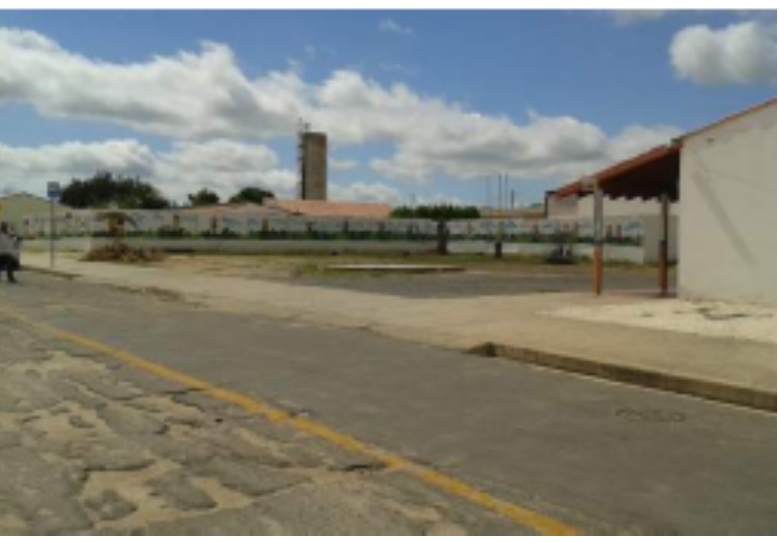

\subsection{As Residências}

Figura 13. Uma das praças "periféricas" observando-se a ausência de equipamentos para uso dos habitantes. Fonte: Quintanilha, 2016.

As residências são um dos elementos mais marcantes na feição física do núcleo. Em sua maioria compreendem habitações unifamiliares térreas, projetadas para a ocupação do território com seus lotes com orientação norte-sul, sem muros frontais. No projeto de Guedes para Pilar foram definidos, primeiramente, três tipos de habitações: as residências unifamiliares térreas, os alojamentos - dedicados ao abrigo dos trabalhadores solteiros, no período da instalação e maior atividade da mineradora, e que atualmente funciona como residência para menores famílias ou casais - e os apartamentos.

A tipologia das residências unifamiliares térreas, originalmente, variava de acordo com o nível do cargo ocupado pelo chefe da família dentro da mineradora, marcando tipologicamente as diferenças sociais dentro do núcleo. Procurando minimizar os impactos de segregação social, tendo em vista que o nível hierárquico dos empregados da mineradora era visivelmente identificado por cada tipologia, Guedes buscou mesclar as casas de diferentes níveis aleatoriamente em cada quadra no intuito de atenuar a estratificação (Figura 14). Porém, o que se observa é que essa diretriz não foi plenamente executada, e Pilar herda até hoje uma certa setorização das tipologias habitacionais - e consequentemente social -, onde se observa a concentração das residências que foram destinadas aos operadores mais adensadamente, com grande concentração das casas de "porta e janela" como ficaram conhecidas as residências mais simples 5 .

Para a definição dos arranjos residenciais, o projeto para Pilar contemplou 9 (nove) tipos de residências unifamiliares térreas, onde variavam a área construída e o número de unidades de cada um dos tipos, bem como suas disposições na malha urbana: se isoladas no terreno ou casas ligadas umas às outras. A maioria das residências eram, normalmente, sem recuos ${ }^{6}$, geminadas (de forma a contribuir com o conforto térmico, tendo em vista que se diminuía a incidência do sol em fachadas), possuíam generoso passeio e uma área de fundos com um grande quintal (onde pode ser observada a maior parte da massa vegetal do núcleo), lembrando as tipologias das cidades coloniais.

Para atender às necessidades e demandas da própria mineradora e de seus trabalhadores, foram estudados e executados, portanto, 9 (nove) projetos residenciais, dividido por padrões diferentes destinados a estratos de trabalhadores e moradores específicos. Algumas residências, as de maior área, contavam com pátios internos, disposto em diferentes arranjos, que tinham como objetivo amenizar o desconforto térmico provocado pelo clima da região. Conforme informações e materiais cedidos pela própria mineradora, foram previstas um total de 1.294 habitações térreas, unifamiliares, com soluções arquitetônicas distintas, definidas da seguinte forma ${ }^{7}$ :

5 Os moradores de Pilar utilizavam, e ainda utilizam, as características das aberturas das fachadas como fator de distinção das residências: enquanto "porta e janela" eram as casas mais simples, as residências de "porta e 2 (duas) janelas" já definia uma habitação maior.

${ }^{6}$ Guedes projetou pequenos recuos aleatórios no alinhamento das testadas das casas, buscando dar um movimento no alinhamento das residências na longa extensão das quadras.

7 As informações de quantitativos bem como os esquemas de plantas baixas aqui apresentados, foram cedidos e disponibilizados pela Caraíba Mineradora S/A quando em visita ao Pilar, em agosto de 2004. 




Figura 14. Distribuição dos lotes habitacionais por níveis hierárquicos. Fonte: Quintanilha, 2016.

Residências de padrão superior (85 unidades): tipos N1 (cargo: diretoria - 01 unidade), N2A (cargo: gerentes - 23 unidades) e N2B (cargo: nível superior e chefe de setor - 61 unidades).

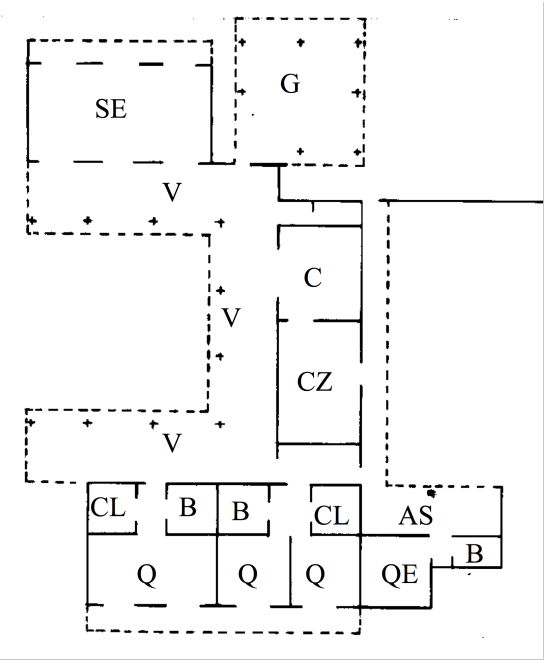

Figura 15. Residência N1 - área: $501,03 \mathrm{~m}^{2}$. Fonte: acervo próprio

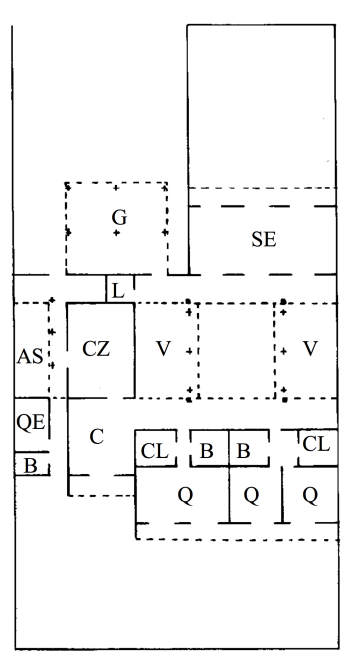

Figura 16. Residência N2A - área: 448,48 $\mathrm{m}^{2}$. Fonte: acervo próprio



Figura 17. Residência N2B - área: $434,76 \mathrm{~m}^{2}$. Fonte: acervo próprio

Residências de padrão médio (137 unidades): tipos N3I (cargo: supervisor - 48 unidades) e N3G (cargo: nível técnico - 89 unidades).



Figura 18. Residência N3I - área: 142,50 m²$^{2}$. Fonte: acervo próprio.

Figura 19. Residência N3G - área: $116,40 \mathrm{~m}^{2}$. Fonte: acervo próprio.

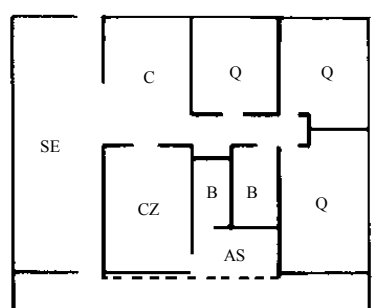


Residências de menor padrão (1.072 unidades): tipos N43D (cargo: operadores - 276 unidades), N42D (cargo: operador - 280 unidades), N53D (cargo: ajudantes de operação - 256 unidades) e N52D (cargo: ajudantes de operação - 260 unidades).

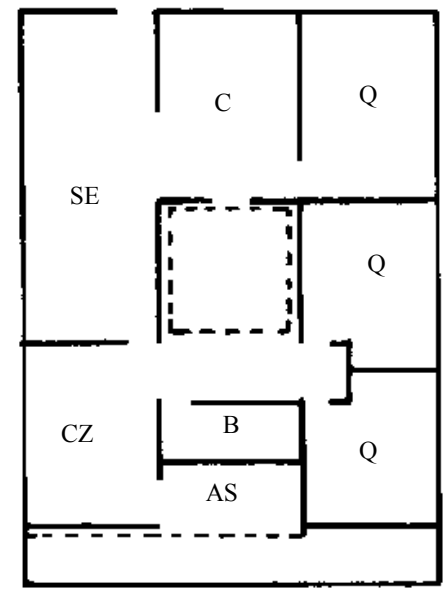

Figura 20. Residência N43D - área: $100,80 \mathrm{~m}^{2}$. Fonte: acervo próprio



Figura 22. Residência N53D (porta e janela) área: $81,00 \mathrm{~m}^{2}$. Fonte: acervo próprio



Figura 24. Residências N5, com 2 ou 3 dormitórios. Fonte: acervo próprio.

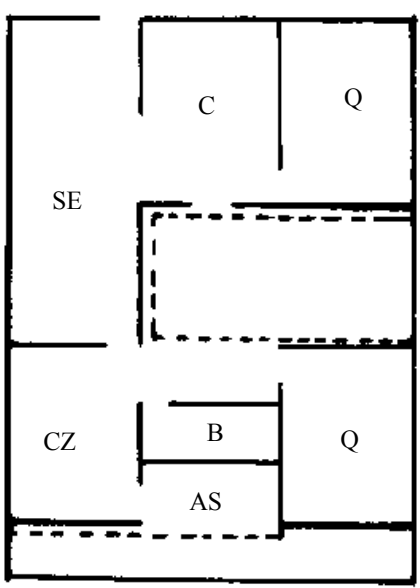

Figura 21. Residência N42D -- Área: $100,80 \mathrm{~m}^{2}$. Fonte: acervo próprio

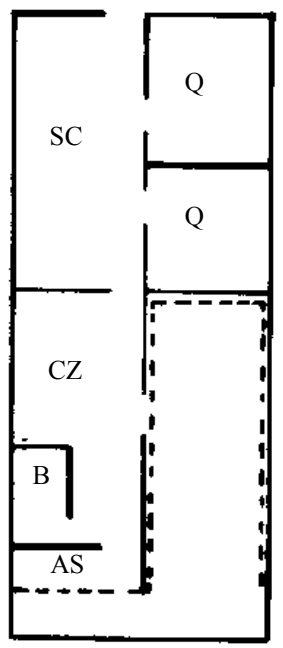

Figura 23. Residência N52D (porta e janela) área: $81,00 \mathrm{~m}^{2}$. Fonte: acervo próprio

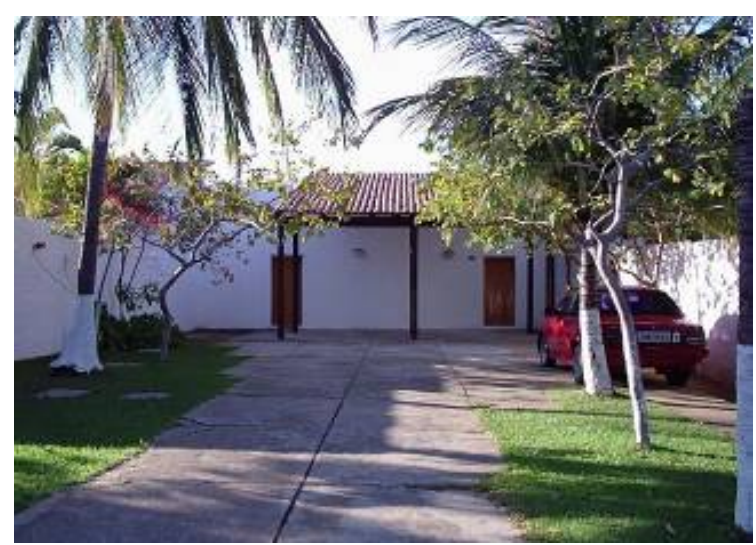

Figura 25. Residências N2B. Fonte: acervo próprio. 


\section{Labor \& Engenho}

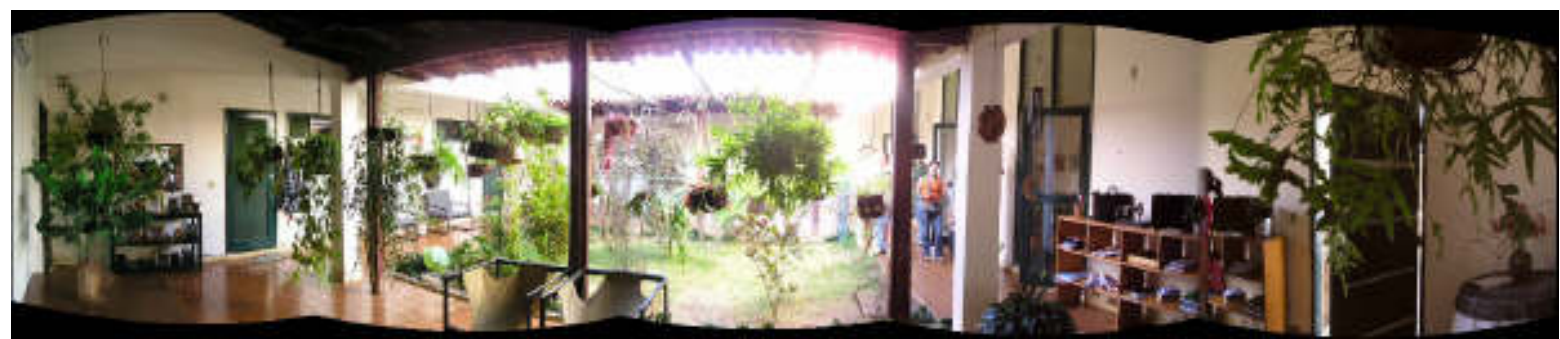

Figura 26. Interior da Residência N2A, pátio interno. Fonte: acervo próprio.

Os alojamentos se destinavam aos solteiros ou aos temporários. Situavam-se nos edifícios centrais, nos andares superiores dos mesmos. Também possuíam diferenciações de organização espacial de acordo com o cargo ocupado na mineradora, possuindo 4 tipos diferentes, conforme as plantas baixas abaixo.
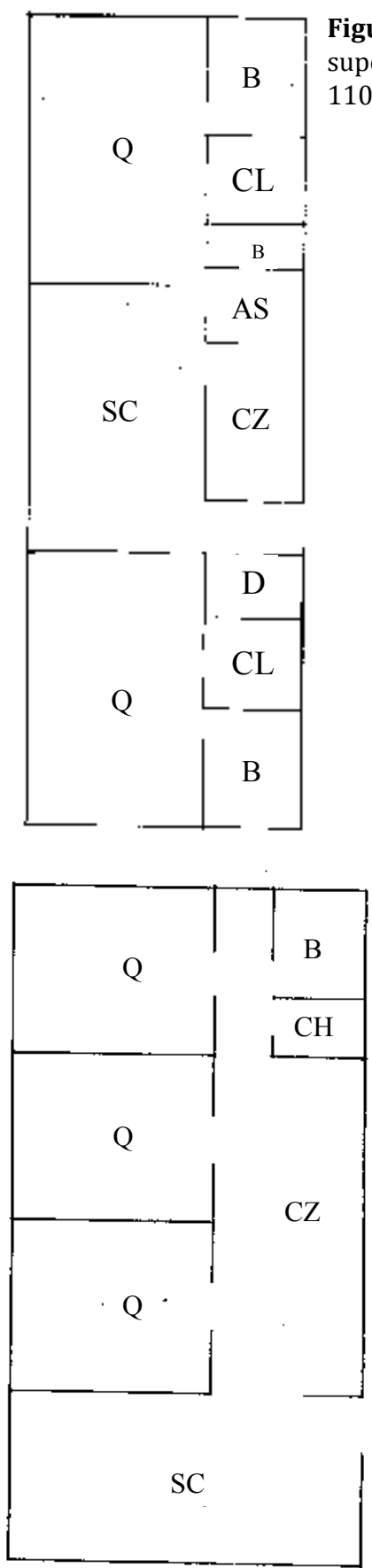

Figura 27. Alojamento ALN 1/2 - cargo: nível superior ou gerente - 10 unidades - Área: $110,88 \mathrm{~m}^{2}$. Fonte: acervo próprio.

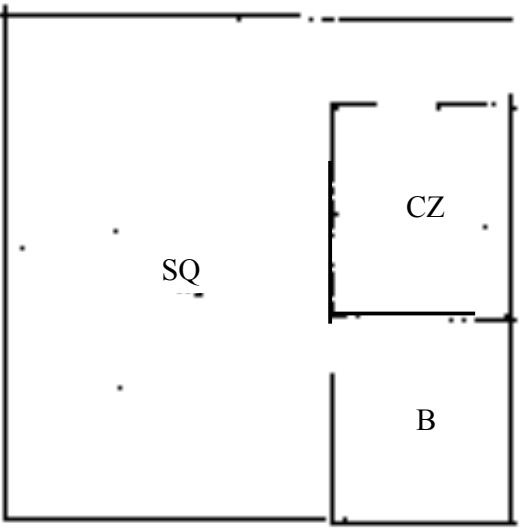

Figura 28. Alojamento ALN3 - cargo: nível técnico 54 unidades - Área: 36,96 m². Fonte: acervo próprio.
Figura 29. Alojamento ALN4 -

cargo: operadores - 34 unidades - Área: 73,92 m². Fonte: acervo próprio.
Figura 30. Alojamento ALN5 cargo: ajudantes de operação 56 unidades - Área: 32,42 m². Fonte: acervo próprio.
B

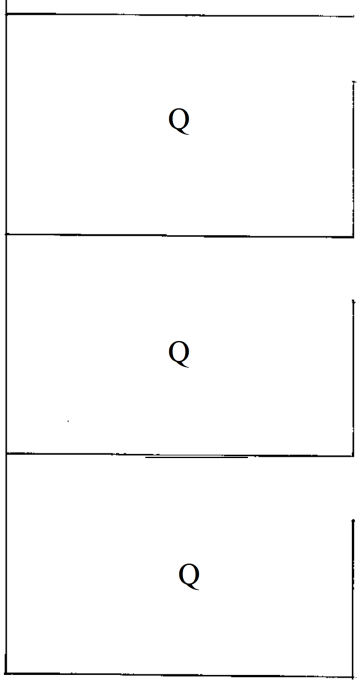


E por fim, como forma habitacional, também foram projetados apartamentos. Os apartamentos assim como as demais outras tipologias habitacionais possuíam disposições diferenciadas de acordo com o cargo dentro da mineradora, de acordo com as plantas baixas que seguem. Estavam localizados nos edifícios centrais e possuíam maior número de unidades em relação aos alojamentos.

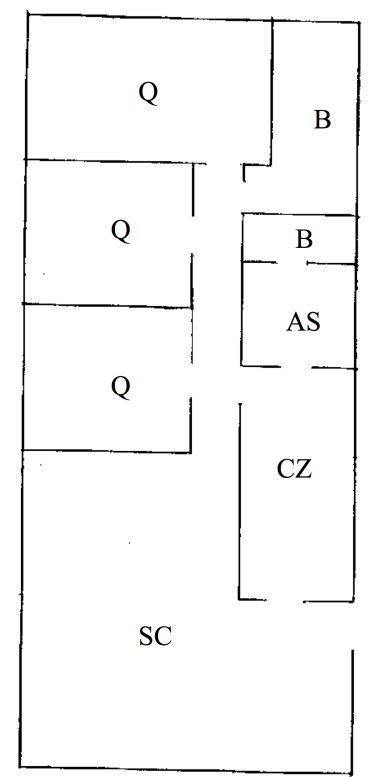

Figura 31. Apartamento APN3 cargo: supervisores -30 unidades - Área: $107,79 \mathrm{~m}^{2}$.

Fonte: acervo próprio.

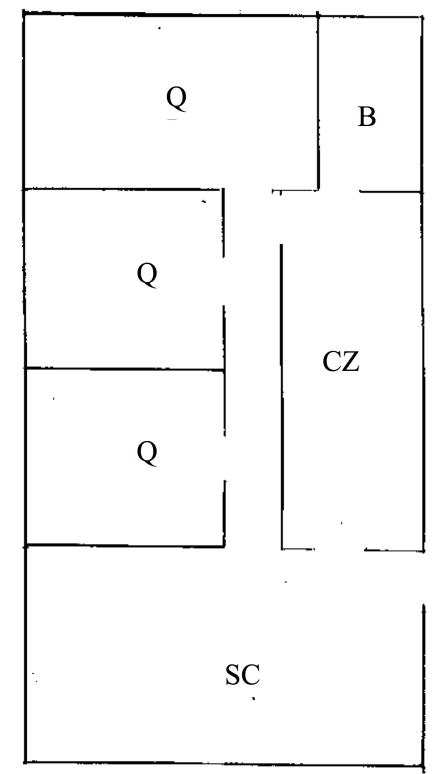

Figura 32. Apartamento APN4 cargo: operadores - 96 unidades Área: $87,06 \mathrm{~m}^{2}$.

Fonte: acervo próprio.

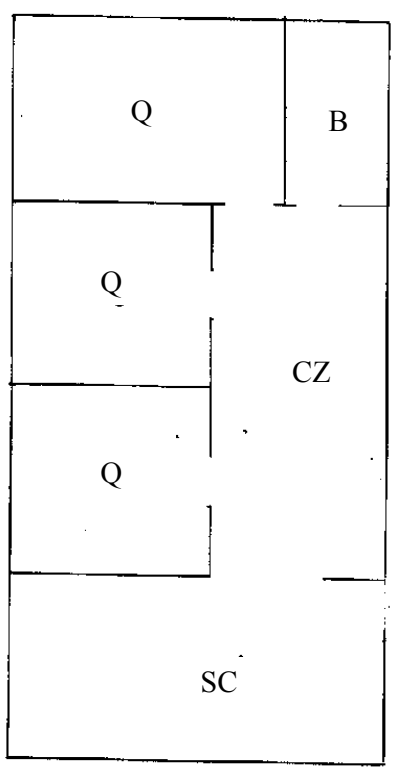

Figura 33. Apartamento APN5 cargo: ajudantes de operação - 48 unidades - Área: 73,92 m². Fonte: acervo próprio.

\subsection{Os Equipamentos}

O distrito possui alguns importantes e necessários equipamentos para seu funcionamento. São centro de atendimento médico, escolas, clubes, igrejas (estas se utilizando das estruturas das residências) que promovem o funcionamento do núcleo, dando-lhe maior infraestrutura. 0 centro de atendimento médico, na saída do núcleo, é equipado para o atendimento de urgência, casos mais graves são encaminhados para Jaguarari ou para as cidades maiores mais próximas - Juazeiro e Senhor do Bonfim. Pilar conta com 4 escolas, sendo 2 de pré-escolar e 2 com ensino fundamental e médio. Conta ainda com dois clubes sociais para lazer, estes previstos no plano original do núcleo, sendo direcionados para estratos diferenciados da sociedade, ou seja, cada clube distinguia seus freqüentadores e associados pelo nível do cargo do funcionário da mineradora, assim como acontecia nas residências.

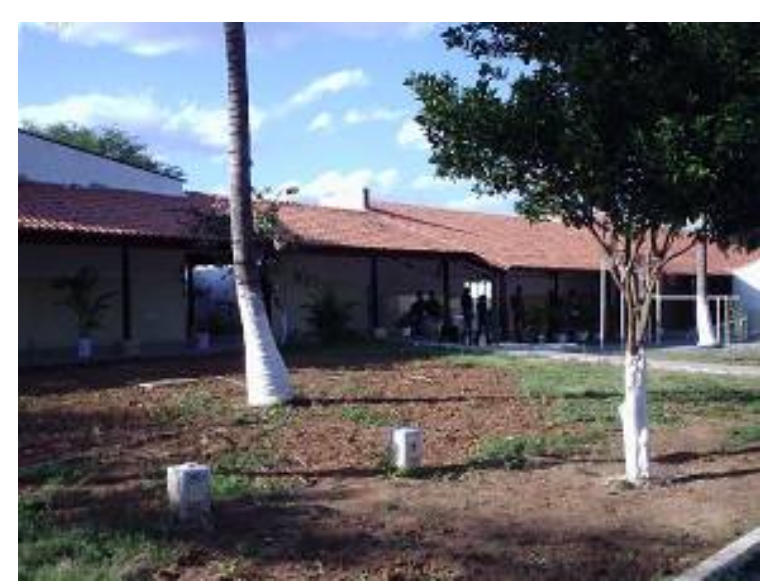

Figura 34. Clube para os funcionários de cargos de maior nível. Fonte: acervo próprio.

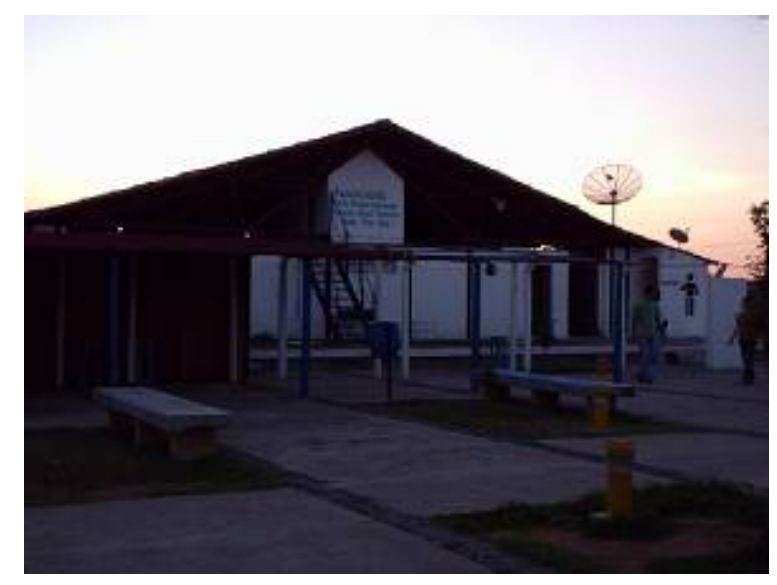

Figura 35. Clube para os funcionários de cargos de menor nível. Fonte: acervo próprio. 


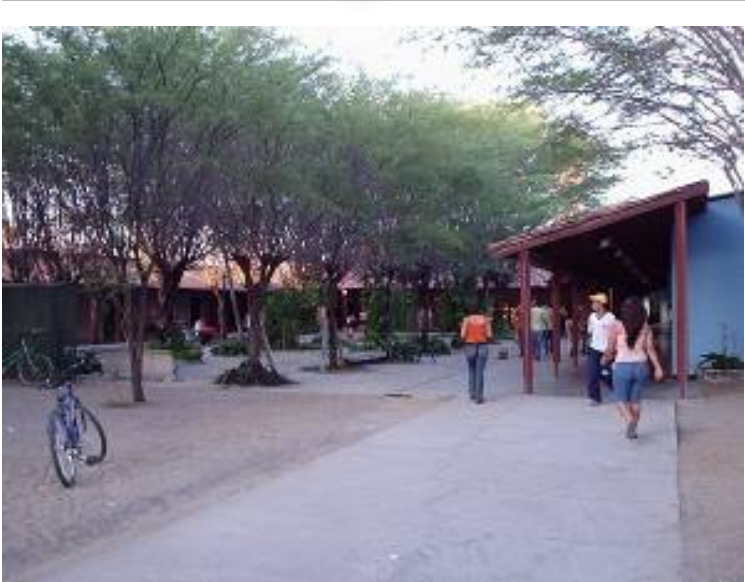

Figura 36. Escola Estadual de Ensino Fundamental e Ensino Médio Seu Amado. Fonte: acervo próprio.

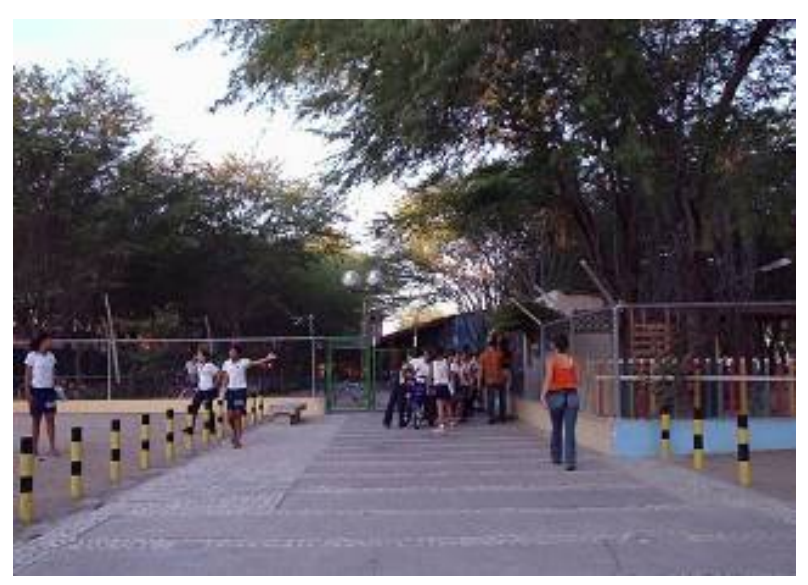

Figura 37. Escola Estadual de Ensino Fundamental e Ensino Médio Seu Amado. Fonte: acervo próprio.

\section{Considerações Finais}

Segundo a Carta de Nizhny Tagil (2003):

O patrimônio industrial compreende os vestígios da cultura industrial que possuem valor histórico, tecnológico, social, arquitectônico ou científico. Estes vestígios englobam edifícios e maquinaria, oficinas, fábricas, minas e locais de processamento e de refinação, entrepostos e armazéns, centros de produção, transmissão e utilização de energia, meios de transporte e todas as suas estruturas e infra-estruturas, assim como os locais onde se desenvolveram actividades sociais relacionadas com a indústria, tais como habitações, locais de culto ou de educação. (grifos nossos)

A construção de núcleos habitacionais para atendimento de demandas emanadas da instalação de indústrias e empresas de exploração de minerais pelo interior do país, deixa um legado de um patrimônio que não deve ser desmerecido ou esquecido. A criação de uma nova cidade, a partir de um planejamento, suscita olhares atentos sobre suas características urbanas, arquitetônicas e paisagísticas, onde a partir de um desejo de um agente público ou privado, são definidos o sítio de instalação, suas formas de funcionamento e sua relação com o existente. As escolhas projetuais impactarão nas atividades que ali serão instaladas, transfigurando como patrimônio não apenas a sua representação física, mas, especialmente, seu legado de memória relacionado à indústria que lhe originou e aos trabalhadores que para lá se deslocaram e que travaram um sentimento identitário. $\mathrm{Ou}$ seja, para além de seus valores tecnológico, científicos e estéticos, o patrimônio industrial se reveste dos valores sociais e de memória como partes integrantes e essenciais para o seu reconhecimento.

Estes valores são intrínsecos aos próprios sítios industriais, a suas estruturas, a seus elementos constitutivos, a sua maquinaria, a sua paisagem industrial, a sua documentação e também aos registros intangíveis contidos na memória dos homens e de suas tradições. (Azevedo, 2010)

Em Pilar, as maiores características arquitetônicas e urbanísticas como o seu traçado ortogonal, com hierarquização das vias, a tipologia horizontal das residências e o centro comercial com edificações centrais destoando do gabarito geral do núcleo, ainda preservam um grande número de exemplares do projeto original. Porém, é possível observar, atualmente, algumas desfigurações de sua arquitetura inicial, apresentando algumas distorções em sua feição física, a partir de intervenções inadequadas. Conforme Bierrenbach (2007):

Se no momento de concepção de Caraíba há um poder centralizador (representado pelo Estado ou pela mineradora) que determina as características da obra e estabelece os modos de utilizá-la, na atualidade o que existe é um poder esfacelado que praticamente não exerce mais controle sobre a cidade, sobre as casas ou sobre os seus habitantes. 
Tais desfigurações são mais sentidas e verificadas nas edificações, especialmente nas residências unifamiliares, onde os proprietários fizeram algumas alterações comprometendo não apenas a arquitetura individual, mas como também a leitura urbana. Observa-se nas reformulações: aberturas de novas janelas e portas, perdendo assim a integridade dos cheios e vazios propostos do projeto original; incorporações de varandas, garagens e áreas de serviço; incorporação também dos pequenos recuos projetados por Joaquim Guedes, no alinhamento das testadas dos lotes, o que acarreta no alinhamento total da quadra; a inserção dos muros presentes em grande número das residências; acréscimos volumétricos, existindo, inclusive, casos de aumento de pavimento em edificações inicialmente térreas; além das substituições de esquadrias e inserção de revestimentos às fachadas, desconfigurando plenamente a feição das residências.

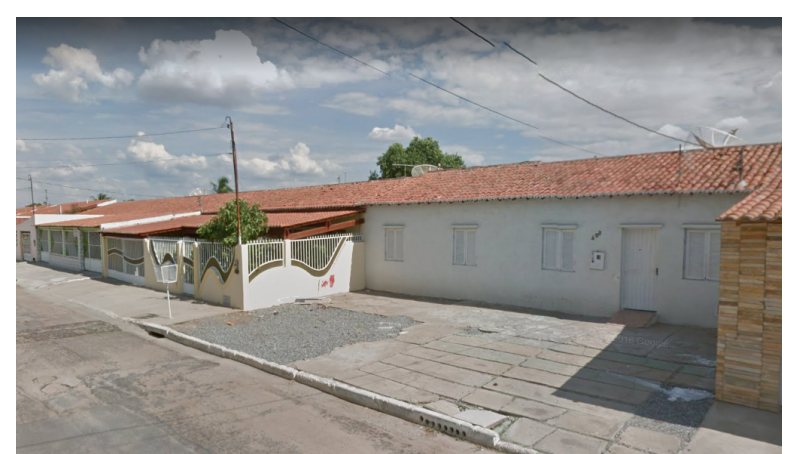

Figura 38. Residência conservada aspectos originais e demais após as intervenções. Fonte: Google, imagem captada em novembro de 2012.

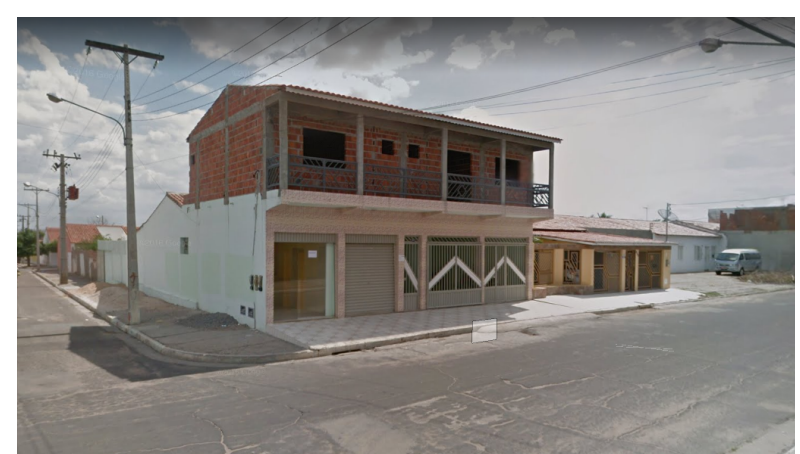

Figura 39. Acréscimo volumétrico em altura de. Fonte: Google, imagem captada em novembro de 2012.

A memória e a imagem do distrito do Pilar carecem de uma atenção mais criteriosa em sua preservação, assim como sua história. Os vestígios vão se perdendo e a inexistência de um organismo que regule e lute pela boa conservação acelera as perdas que já vêm sendo vivenciadas e sentidas nos últimos anos. A implantação, a história e as particularidades da antiga cidade de Caraíba, tornam sua existência e experiência única na caatinga nordestina. A leitura e investigação das cidades construídas para abrigar e dar apoio às empresas de exploração de recursos naturais promovem a preservação de sua existência, sua importância e, especialmente, sua memória. Isso pode ser evidenciado pelo tombamento de outros núcleos que nasceram sob este mesmo contexto, a exemplo da Vila Serra do Navio, projetado na década de 1950 para exploração de manganês no Amapá, e tombado como Patrimônio Cultural Brasileiro pelo IPHAN em 2010.

Por outro lado, após 40 anos do início dos estudos para a instalação da cidade de Caraíba, seus habitantes convivem com a sempre presente ameaça de extinção da mineradora e o destino que pode ser traçado para o Pilar. Isolado de outros núcleos habitacionais, Pilar vive hoje uma busca, correndo contra o tempo, de uma nova fonte de econômica que possa manter e sustentar o antigo núcleo da mineradora, podendo andar com suas próprias pernas (Figura 40). Para além da atividade comercial que foi sendo fortalecida no decorrer do tempo, uma das alternativas encontrada por seus moradores está na cultura caprina, podendo retirar desde a matéria-prima da carne até produzir artesanato utilizando este animal como fonte. Hoje, a partir da promoção de mobilizações de suas organizações sociais, seus habitantes almejam a emancipação do distrito, conjuntamente com a localidade de Santa Rosa, que juntos somam uma população de 15 mil habitantes, o que possibilitaria um fortalecimento e crescimento local. Caso não haja uma forte vontade política e social, associada a investimentos econômicos, Pilar está fadada à falência geral podendo seguir o exemplo de outras cidades mineradoras que ficaram esquecidas, resultando na perda de importante patrimônio da história.

Figura 40. Panfleto publicitário promovido por organizações sociais de Pilar. Fonte: acervo próprio.

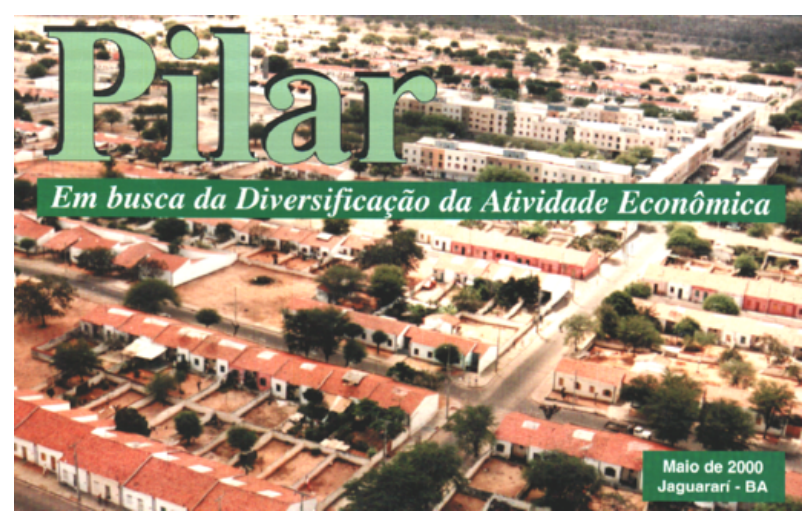




\section{Referências}

Azevedo, E. B. de (2010). O Patrimônio Industrial no Brasil. Revista Eletrônica Arq. Urb., 03. São Paulo: Universidade São Judas Tadeu (USJT). Recuperado de: http://www.usjt.br/arq.urb/numero_03/2arqurb3esterezilda.pdf

Bierrenbach, A. C. de S. (2007) A Caraíba de Joaquim Guedes. A trajetória de uma cidade no sertão. Portal Vitruvius. Arquitextos 087.02. 08. Recuperado de: http://www.vitruvius.com.br/revistas/read/ arquitextos/08.087/217

Camargo, M. J. de (2000). Joaquim Guedes. São Paulo: Cosac Naify, 2000.

The International Committee for the Conservation of the Industrial Heritage (TICCIH) (2003). Carta Nizhny Tagil sobre o Patrimônio Industrial. Nizhny Tagil. Recuperado de: http://

www.patrimonioindustrial.org.br/modules.php?name=News\&file=article $\&$ sid $=29$

Espallargas, L. (2009) Caraíba e Serra do Navio: a construção da cidade brasileira. Revista Eletrônica Arq.Urb. 02. São Paulo: Universidade São Judas Tadeu (USJT). Recuperado de: http://www.usjt.br/arq.urb/ numero_02/artigo_luis.pdf

Farias, R. S. S. (2003) Entre o projetar e o realizar: Os (des)caminhos de uma trajetória incompleta: 0 Projeto da Vila de Nova Barcarena-PA. In: Seminário Arquitetura e Conceito, 2003, Belo Horizonte. Belo Horizonte: UFMG.

Filho, R. da S. (s.d.) A riqueza do sertão da Bahia. Recuperado de: http://www.minerios.com.br/277/ minerios_cobre2.htm

Guedes, J. (2006) Monumentalidade x Cotidiano: a função pública da Arquitetura. Mínimo Denominador Comum - Revista de Arquitetura e Urbanismo. 1(3). Recuperado de: https:// revistamdc.files.wordpress.com/2008/12/mdc03-txt05.pdf

Sanna, A. (2003) Città Nuove e Villaggi Operai a Bocca di Miniera. Interpretazioni "Autarchiche" della Città Giardino. In: AYMERICH, Carlo; MIGONE RETTIG, Jaime; STOCHINO, Monica (org.). Mostra e Convegno Internazionale Archeologia Industriale: esperienze per la valorizzazione in Cile e in Sardegna. Roma: Gangemi, p. 103.

Soriano, A. G. W. (2006). Pilar, um oásis no sertão baiano. Recife, I Docomomo N-NE. 